\title{
Altered pathogenesis in encephalomyocarditis virus ( $D$ variant)-infected diabetes-susceptible and resistant strains of mice
}

\author{
K. L. Gaines, S. G. Kayes and G. L. Wilson \\ Department of Anatomy, University of South Alabama, College of Medicine Mobile, Alabama, USA
}

Summary. The D variant of encephalomyocarditis virus (EMCV-D) induces a diabetes mellitus-like disease in male $\mathrm{SJL} / \mathrm{J}$ mice. Other inbred strains, while resistant to the diabetogenic effect, exhibit strikingly different responses to this virus. In these studies, infection of diabetes resistant $\mathrm{C} 3 \mathrm{H}$ mice with the $\mathrm{D}$ variant produces massive acute pancreatitis with little apparent direct islet cell involvement. This exocrine tropism is not altered when $\mathrm{C} 3 \mathrm{H}$ mice with an inherent macrophage defect are infected, and appears to be a gender-specific phenomenon, with female $\mathrm{C} 3 \mathrm{H}$ mice resistant to this exocrine involvement. Long-term infection of both male and female $\mathrm{C} 3 \mathrm{H}$ mice does not change their response to the virus. Castration of male $\mathrm{C} 3 \mathrm{H}$ mice, using a protocol that has been reported to block the diabetogenic effect of this virus, does not alter the development of this acinar lesion. The B variant of EMCV does not induce acinar destruction, nor is it diabetogenic. However, preinfection with the $B$ variant 3 days prior to infection with the $\mathrm{D}$ variant does protect against the development of the exocrine lesion. Coinfection with equal doses of the two variants also protects against this lesion, as does coinfection with a lower dose of $B$ variant. Therefore, the host response that is generated against the $\mathrm{B}$ variant appears to be responsible for this protection from $\mathrm{D}$ variant exocrine destruction. Due to the short time frame, it is unlikely that this protection is the result of an antibody response. Rather, this data is more consistent with an interferon response generated against the B variant that would inhibit replication of the $D$ variant.

Key words: Encephalomyocarditis virus, diabetes mellitus, pancreatitis, D variant, B variant, castration, viral tropism.
A viral etiology for Type 1 (insulin-dependent) diabetes mellitus has been suggested by the abrupt onset [1] and seasonal variation [2] sometimes seen in this disease. The description of a murine model for Type 1 diabetes induced by encephalomyocarditis (EMCV) virus has provided a means for examining experimentally the possible role of viruses in Type 1 diabetes [3-6]. Two strains of EMCV virus were initially isolated - an $\mathrm{E}$ strain that is highly neurotropic, and an $M$ strain that produces myocarditis with little central nervous system involvement [7]. This $M$ strain is capable of inducing a diabetes mellitus-like disease by selective destruction of pancreatic $\beta$ cells in certain inbred strains of mice [8]. Other inbred strains are resistant to these diabetogenic effects, even though these animals do sustain a viral infection. Further investigations with this virus resulted in the isolation of two variants, a $\mathrm{B}$ variant which is nondiabetogenic, and a $\mathrm{D}$ variant which does cause the disease [9]. Little has been reported on the effects of this highly diabetogenic $D$ variant in strains of mice that have previously been shown to be resistant to the diabetogenic effects of the $M$ strain. Therefore, it was the in- tent of the present investigation to compare the pathogenesis of infection of the $\mathrm{D}$ variant in the pancreata of diabetes-susceptible $\mathrm{SJL} / \mathrm{J}$ mice to that of resistant $\mathrm{C} 3 \mathrm{H}$ mice. Recent work has suggested that factors which activate macrophages can protect susceptible mice from the diabetogenic effects of the $\mathrm{D}$ variant $[10]$. These findings raise the possibility that differences in macrophage activation could account for the differences in susceptibility to diabetes seen in different inbred strains. A variant of the $\mathrm{C} 3 \mathrm{H}$ mouse strain $(\mathrm{C} 3 \mathrm{H} / \mathrm{HeJ})$ has been found to exhibit a defect in macrophage differentiation when stimulated with lipopolysaccharide [11]. In order to determine if this macrophage defect might render these mice more susceptible to the diabetogenic effects of the $\mathrm{D}$ variant, the pathogenesis of infection in the macrophage deficient mice was compared with that seen in diabetes - susceptible $\mathrm{SJL} / \mathrm{J}$ and macrophage - normal $\mathrm{C} 3 \mathrm{H}$ animals. Other studies were performed to compare the pathogenesis of infection in male and female $\mathrm{C} 3 \mathrm{H}$ mice. Finally, the effects of infection with the nondiabetogenic $\mathrm{B}$ variant in $\mathrm{C} 3 \mathrm{H}$ mice were studied. 


\section{Materials and methods}

\section{Animals}

Inbred strains of mice used in this study were $\mathrm{SJL} / \mathrm{J}, \mathrm{C} 3 \mathrm{H} / \mathrm{HeJ}$, and $\mathrm{C} 3 \mathrm{HeB} / \mathrm{FeJ}$. All strains were obtained from the Jackson Laboratory, Bar Harbor, MA, USA, and were between 6 and 12 weeks of age at the time of infection. The animals were provided with water and Purina Laboratory Rodent Chow ad libitum and were housed by the Department of Comparative Medicine. Both males and females were studied when appropriate.

\section{Virus}

Plaque-isolated $D$ and $B$ variants of encephalomyocarditis virus were kindly supplied by Dr. Ji-Won Yoon (Laboratory of Oral Medicine, National Institute of Dental Research, National Institutes of Health, Bethesda, MD, USA). The viruses were titered on secondary-mouseembryo cells, then stored at $-70^{\circ}$ until used. Dilutions of each variant were prepared in Hank's Balanced Salt Solution (Flow Laboratories, McLean, VA, USA) at $1 \times 10^{6}$ plaque-forming $\mathrm{u} / \mathrm{ml}$. Each animal received $0.1 \mathrm{ml}$ of the virus or diluent intraperitoneally $\left(1 \times 10^{5}\right.$ plaque-forming units per animal).

\section{Blood glucose determination}

Blood samples were obtained from nonfasted animals via the retroorbital venous plexus using heparinized capillary tubes. Samples were taken prior to infection and at 2-day intervals thereafter. Plasma glucose concentrations were determined by a glucose oxidase method employing a Beckman II glucose analyzer (Beckman Instruments, Fullerton, CA, USA). Nonfasting blood glucose values greater than 5 standard deviations from the mean of control uninfected mice were considered diabetic. Each mouse strain was considered independently, since control blood glucose levels tended to vary between each strain.

\section{Glucose tolerance testing}

Glucose tolerance testing was performed on nonfasted mice prior to infection, and at 7-day intervals thereafter. Each mouse received an injection of glucose intraperitoneally at a concentration of $2 \mathrm{mg} / \mathrm{g}$ body weight. Blood samples were obtained prior to the glucose administration, and $60 \mathrm{~min}$ postinjection. Blood glucose concentrations that were 5 standard deviations above mean control values $1 \mathrm{~h}$ after the glucose challenge were considered to be diabetic.

\section{Pancreatic insulin determination}

Frozen pancreata were weighed and extracted with cold acidified ethanol, and the concentration of immunoreactive insulin was determined by radioimmunoassay utilizing a back titration method [12]. Results were expressed as the total number of units of insulin per gram wet weight of pancreas.

\section{Histology}

At killing on day 5 post-infection, pancreata were removed and bisected along a longitudinal plane. Half of the pancreas was frozen at $-70^{\circ}$ for pancreatic insulin determination, while the other half was fixed in Bouin's solution, embedded in paraffin, then sectioned at $6 \mu \mathrm{m}$ for histological evaluation. These sections were stained by hematoxylin and eosin, or by immunoperoxidase techniques [13], to demonstrate alpha, beta, delta, and pancreatic polypeptide cells.

\section{Histological evaluations}

The degree of pancreatitis was determined by two independent scorers on a scale of 0 to 4 , with 1 equaling a score of less than $25 \%$ and 4 a score corresponding to greater than $75 \%$ inflammation and necrosis of the exocrine pancreas in a $40 \times$ field. Ten fields per slide were scanned randomly and the mean score for each slide was determined. Fields showing no exocrine damage received a score of 0 .

\section{Castration of male mice}

$\mathrm{C} 3 \mathrm{H} / \mathrm{HeJ}$ and $\mathrm{SJL} / \mathrm{J}$ male mice were castrated under light ether anaesthesia at 5 weeks of age. Sham operation involved opening of the scrotal sac and identification of the testes. Controls were not operated upon. The animals were allowed to recover for 10 days after castration, then were inoculated with $1 \times 10^{5}$ plaque-forming units of EMCV-D intraperitoneally. Blood glucose determinations were made prior to infection and 3 and 5 days post-infection. At killing on day 5 , the pancreata were removed for pancreatic insulin determination and histological evaluation. The success of the castration procedure was verified at necropsy.

\section{Preinfection with the $B$ variant of $E M C V$}

Male $\mathrm{C} 3 \mathrm{H} / \mathrm{HeJ}$ mice and $\mathrm{SJL} / \mathrm{J}$ mice were injected intraperitoneally with $1 \times 10^{5}$ plaque-forming units per animal of the $B$ variant of EMCV. After 3 days the mice were infected with an equal concentration of the D variant of EMCV. Blood glucose levels were measured

Table 1. Effect of varying EMCV infection regimens on blood glucose levels and the development of overt diabetes

\begin{tabular}{|c|c|c|c|c|}
\hline \multirow{2}{*}{$\begin{array}{l}\text { Treatment } \\
\text { groups }\end{array}$} & \multicolumn{2}{|c|}{ Blood glucose (mg/dl) } & \multirow{2}{*}{$\begin{array}{l}\% \\
\text { Diabetic }\end{array}$} & \multirow[t]{2}{*}{$n$} \\
\hline & $\begin{array}{l}\text { Pre } \mathrm{D} \\
\text { variant }\end{array}$ & 5 days & & \\
\hline \multicolumn{5}{|c|}{$E M C V-D$ infected } \\
\hline $\mathrm{SJL} / \mathrm{J}$ & $177 \pm 6$ & $442 \pm 31$ & 90 & 23 \\
\hline $\begin{array}{c}\mathrm{C} 3 \mathrm{H} / \mathrm{HeJ} \\
\text { (males) }\end{array}$ & $159 \pm 7$ & $150 \pm 8$ & 0 & 53 \\
\hline $\begin{array}{l}\mathrm{C} 3 \mathrm{H} / \mathrm{HeJ} \\
\text { (females) }\end{array}$ & $101 \pm 6$ & $120 \pm 9$ & 0 & 5 \\
\hline $\mathrm{C} 3 \mathrm{HeB} / \mathrm{FeJ}$ & $128 \pm 8$ & $123 \pm 9$ & 0 & 11 \\
\hline \multicolumn{5}{|c|}{$E M C V-B$ infected } \\
\hline $\mathrm{SJL} / \mathrm{J}$ & $164 \pm 10$ & $179 \pm 5$ & 0 & 9 \\
\hline $\mathrm{C} 3 \mathrm{H} / \mathrm{HeJ}$ & $150 \pm 5$ & $154 \pm 7$ & 0 & 16 \\
\hline \multicolumn{5}{|c|}{$\begin{array}{l}\text { Preinfection } \\
\text { with EMCV-B } \\
\text { before EMCV-D }\end{array}$} \\
\hline $\mathrm{SJL} / \mathrm{J}$ & $133 \pm 7$ & $194 \pm 18$ & 8 & 12 \\
\hline $\mathrm{C} 3 \mathrm{H} / \mathrm{HeJ}$ & $130 \pm 5$ & $130 \pm 8$ & 0 & 13 \\
\hline \multicolumn{5}{|l|}{ Coinfection } \\
\hline \multicolumn{5}{|c|}{$\begin{array}{l}\text { Equal doses of } \\
\text { EMCV-B and D }\end{array}$} \\
\hline $\mathrm{C} 3 \mathrm{H} / \mathrm{HeJ}$ & $191 \pm 3$ & $178 \pm 16$ & 0 & 14 \\
\hline \multicolumn{5}{|c|}{$\begin{array}{l}\text { Unequal doses of } \\
\text { EMCV-B and D }\end{array}$} \\
\hline $\begin{array}{c}\mathrm{C} 3 \mathrm{H} / \mathrm{HeJ} \\
(1: 100 ; \mathrm{B}: \mathrm{D})\end{array}$ & $205 \pm 11$ & $175 \pm 11$ & 0 & 17 \\
\hline
\end{tabular}

Blood glucose levels in virus-infected mice prior to infection (Pre) and 5 days post-infection. Results are expressed as the mean \pm SEM. The percentage of animals that became diabetic, based upon elevations in blood glucose levels greater than 5 standard deviations above mean control values, are also given. Only SJL/J mice exhibited diabetes using these criteria 
prior to infection with either virus and at 2-day intervals after infection. Pancreata were removed for pancreatic insulin determination and histological evaluation. Control mice did not receive virus, or received either the B or D variant alone.

\section{Coinfection with equal dosages of $B$ and $D$ variants of EMCV}

Male $\mathrm{C} 3 \mathrm{H} / \mathrm{HeJ}$ mice were intraperitoneally infected concomitantly with $1 \times 10^{5}$ plaque-forming units of both the $B$ and $D$ variants of EMCV. Blood glucose concentrations were determined prior to infection and 3 and 5 days post-infection. Pancreata were removed at killing on day 5 for pancreatic insulin determination and histological evaluation. Control mice did not receive virus, or received B or D variants alone.

\section{Coinfection with unequal dosages of $B$ and $D$ variants of $E M C V$}

Male $\mathrm{C} 3 \mathrm{H} / \mathrm{HeJ}$ mice were infected intraperitoneally with $1 \times 10^{5}$ plaque-forming units of EMCV-D along with $1 \times 10^{3}$ plaque-forming units of the $B$ variant of EMCV. Blood glucose levels were determined before infection, and at 2-day intervals thereafter. Pancreata were removed at killing on day 5 and processed for pancreatic insulin determination and histological evaluation of viral damage.

\section{Statistical analysis}

Results were expressed as the mean \pm the standard error of the mean. The significance of differences was assessed using an unpaired Student's t-test. Only values with $p<0.01$ were regarded as significant.

\section{Results}

\section{Effect of EMCV-D on blood glucose levels}

Neither resistant strain, $\mathrm{C} 3 \mathrm{HeB} / \mathrm{FeJ}$ males nor macrophage-defective $\mathrm{C} 3 \mathrm{H} / \mathrm{HeJ}$ males, exhibited elevations in blood glucose at any time during infection with EMCV-D. Female $\mathrm{C} 3 \mathrm{H} / \mathrm{HeJ}$ mice also did not show any change in blood glucose levels for the duration of the experiments (Table 1 ).

In comparison, $\mathrm{SJL} / \mathrm{J}$ male mice were found to be hyperglycaemic by 3 days post-infection and remained diabetic until killing on day 5 . The total percentage of $\mathrm{SJL} / \mathrm{J}$ mice that became diabetic in response to the $\mathrm{D}$ variant of EMCV was $90 \%$ (Table 1).

\section{Effect of EMCV-D on pancreatic insulin levels}

To help determine the degree of $\beta$-cell involvement in the infection, pancreatic insulin levels were determined 5 days post-infection and compared to uninfected controls of these strains. Diabetes-resistant C3H-HeJ mice showed reduced levels of pancreatic insulin. These mice, however, were not overtly diabetic, and did not became hyperglycaemic during the course of infection (Table 2). The levels of pancreatic insulin were also found to be significantly reduced $(p<0.01)$ in $\mathrm{SJL} / \mathrm{J}$ mice (Table 2).
Table 2. Effect of various treatments on pancreatic insulin concentrations in virus-infected mice

\begin{tabular}{llr}
\hline Treatment groups & $\mathrm{U} / \mathrm{g}$ & $n$ \\
\hline Controls (males) & & \\
C3H/HeJ & $1.99 \pm 0.14$ & 37 \\
SJL/J & $1.80 \pm 0.33$ & 7 \\
EMCV-D - infected & & \\
$\quad$ Males (5 days) & & \\
$\quad$ C3H/HeJ & $0.91 \pm 0.09$ & 39 \\
SJL/J & $0.79 \pm 0.10$ & 28 \\
Females (5 days) & $2.73 \pm 0.27$ & 5 \\
$\quad$ C3H/HeJ & & \\
EMCV-D - infected & & \\
Long term (21 days) & & \\
C3H/HeJ & & \\
$\quad$ Males & $1.07 \pm 0.11$ & 9 \\
$\quad$ Females & $1.21 \pm 0.26$ & 12 \\
EMCV-B - infected & & \\
C3H/HeJ & $1.59 \pm 0.11$ & 16 \\
SJL/J & $1.81 \pm 0.33$ & 9 \\
Preinfection - with EMCV-B before EMCV-D & & \\
C3H/HeJ & $2.60 \pm 0.33$ & 11 \\
Coinfection - with EMCV-B and D & & \\
C3H/HeJ & & \\
$\quad$ Equal doses & $1.58 \pm 0.2$ & 14 \\
Unequal doses & $0.81 \pm 0.10$ & 17 \\
(1:100; B:D) & & \\
\hline
\end{tabular}

Effect of various treatments on the levels of pancreatic insulin present in EMCV-infected mice. Concentrations of pancreatic insulin are expressed as units of insulin per gm wet weight. All mice are males unless otherwise indicated. The D variant of EMCV produces a reduction in pancreatic insulin in males of both diabetes-resistant and susceptible strains at 5 days post-infection (mean \pm SEM)

Table 3. Effect of various infection regimens on the development of pancreatitis in $\mathrm{C} 3 \mathrm{H}$ mice

\begin{tabular}{|c|c|c|c|}
\hline Treatment groups & $\begin{array}{l}\text { Pancreatitis } \\
\text { score } \\
(\bar{x} \pm S E M)\end{array}$ & $\begin{array}{l}\% \text { Mice } \\
\text { with }>50 \% \\
\text { pancreatitis }\end{array}$ & $n$ \\
\hline$E M C V-D$ infected males & $2.45 \pm 0.16$ & 90 & 41 \\
\hline EMCV-D infected females & $0.2 \pm 0.06$ & 0 & 6 \\
\hline$E M C V-B$ infected males & $0.14 \pm 0.06$ & 0 & 15 \\
\hline $\begin{array}{l}\text { Preinfection with EMCV-B } \\
\text { before EMCV-D }\end{array}$ & $0.48 \pm 0.21$ & 11 & 18 \\
\hline $\begin{array}{l}\text { Coinfection with equal doses } \\
\text { of EMCV-B and D }\end{array}$ & $0.02 \pm 0.01$ & 0 & 15 \\
\hline $\begin{array}{l}\text { Coinfection with unequal } \\
\text { doses of EMCV-B } \\
\text { and D }(1: 100 ; \mathrm{B}: \mathrm{D})\end{array}$ & $1.16 \pm 0.29$ & 29 & 17 \\
\hline Castrates & $2.10 \pm 0.4$ & 64 & 11 \\
\hline Sham-operated & $2.19 \pm 0.39$ & 100 & 6 \\
\hline Controls & 0 & 0 & 22 \\
\hline
\end{tabular}

The amount of exocrine damage caused by various treatments with virus-infected $\mathrm{C} 3 \mathrm{H} / \mathrm{HeJ}$ mice was scored on a 0 to 4 scale. Only the $\mathrm{D}$ variant induced a significant difference in scoring of pancreatitis in these mice $(p<0.01)$. All mice are males unless otherwise indicated 


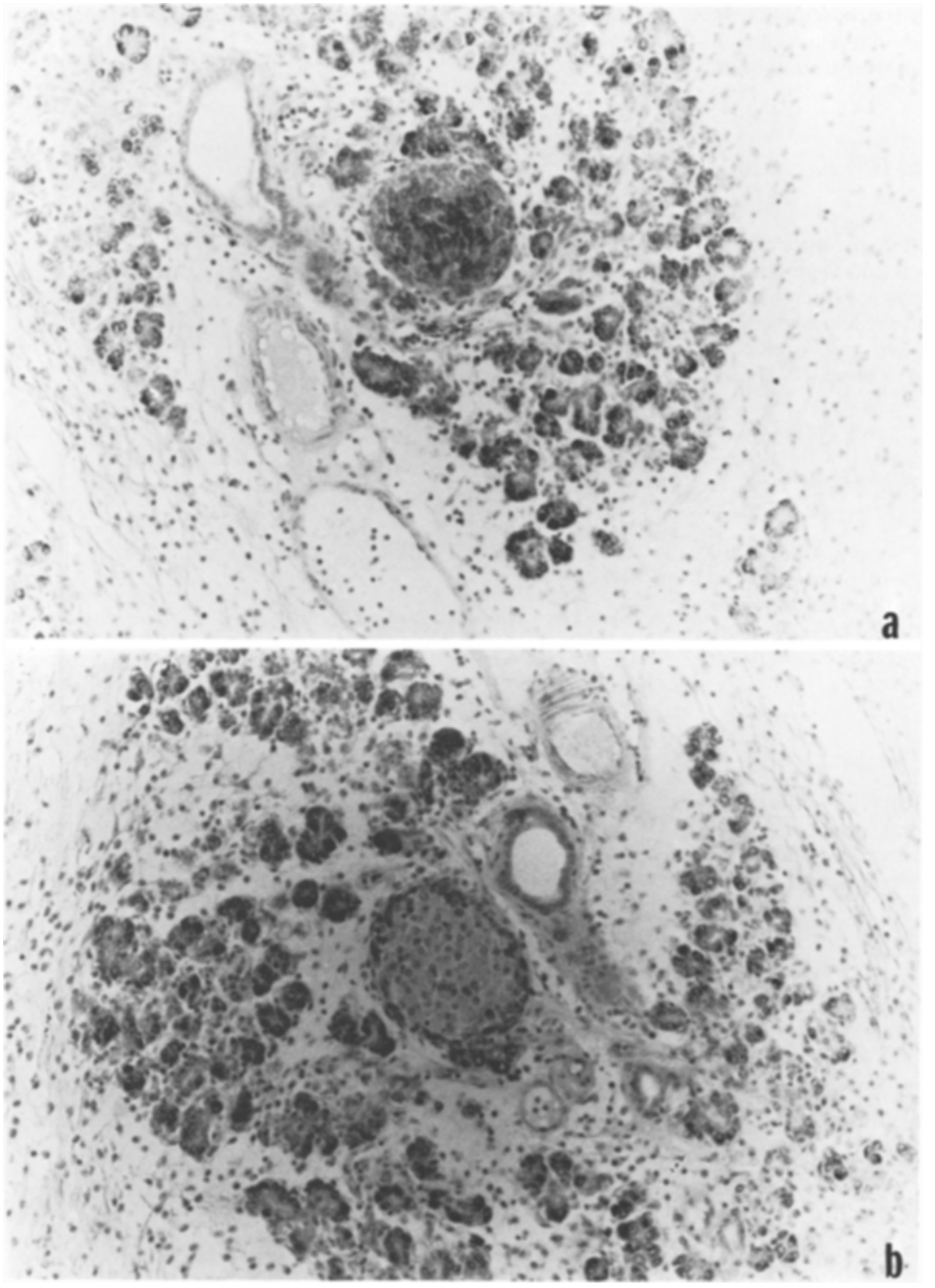

Fig. 1 a and b. Pancreata from a C3H/HeJ mouse 5 days after infection with EMCV-D. a The tissue on this slide has been stained by an immunoperoxidase technique employing anti-insulin serum to reveal insulin containing B cells. A normal appearing islet containing many positive-staining B cells can be seen surrounded by extensive acinar cell necrosis. b A serial section of the same tissue as (a) stained by an immunoperoxidase technique employing anti-glucagon serum to reveal glucagon containing A cells. Positive staining A cells can be identified at the periphery of the islet

\section{Histopathologic changes in the pancreas of $E M C V-D$ infected mice}

$\mathrm{C} 3 \mathrm{H} / \mathrm{HeJ}$ resistant mice exhibited a different lesion than did SJL/J mice. Massive, acute pancreatitis was seen, characterized by destruction of acini, fat necrosis, and mononuclear cell inflammatory infiltration of the exocrine pancreas. However, little direct islet involvement was observed. Sections of pancreas from each $\mathrm{C} 3 \mathrm{H} / \mathrm{HeJ}$ mouse treated with the $\mathrm{D}$ variant were scored for exocrine involvement on a scale of 0 to 4 (Table 3 ). Ninety percent of all $\mathrm{C} 3 \mathrm{H} / \mathrm{HeJ}$ mice infected with EMCV-D exhibited acinar destruction scored at $50 \%$ or greater involvement of pancreas. Immunoperoxidase staining showed relatively unaffected insulin-containing $\beta$, and glucagon-containing alpha cells (Fig.1).
These islets were free of insulitis. However, it was evident that some islets were damaged in areas of extensive exocrine necrosis.

\section{Infection of macrophage normal $\mathrm{C} 3 \mathrm{H} / \mathrm{HeJ}$ mice}

Since $\mathrm{C} 3 \mathrm{H} / \mathrm{HeJ}$ mice posses a macrophage defect, macrophage normal $\mathrm{C} 3 \mathrm{H} \mathrm{Heb} / \mathrm{FeJ}$ mice were infected to see if the altered tropism prevailed. An acute acinar susceptibility was observed in these macrophage normal mice (histology index $2.06 \pm 0.31, n=6$ ).

\section{Infection of male vs. female $\mathrm{C} 3 \mathrm{H} / \mathrm{HeJ}$ mice with $E M C V-D$}

In order to determine if the exocrine involvement seen in $\mathrm{C} 3 \mathrm{H} / \mathrm{HeJ}$ mice was found in both sexes, female 
Table 4. GTT values in long-term infection of $\mathrm{C} 3 \mathrm{H} / \mathrm{HeJ}$ mice with EMCV-D

\begin{tabular}{|c|c|c|c|c|}
\hline \multirow{2}{*}{$\begin{array}{l}\mathrm{C} 3 \mathrm{H} / \mathrm{HeJ} \\
\text { mice }\end{array}$} & \multicolumn{4}{|c|}{ Days post-infection } \\
\hline & Pre & 7 & 14 & 21 \\
\hline \multicolumn{5}{|l|}{ Males } \\
\hline $0 \mathrm{~min}$ & $\begin{array}{l}211 \pm 24 \\
(n=13)\end{array}$ & $\begin{array}{l}166 \pm 61 \\
(n=11)\end{array}$ & $\begin{array}{l}202 \pm 40 \\
(n=8)\end{array}$ & $\begin{array}{l}185 \pm 47 \\
(n=7)\end{array}$ \\
\hline $60 \mathrm{~min}$ & $231 \pm 30$ & $213 \pm 66$ & $245 \pm 72$ & $206 \pm 63$ \\
\hline \multicolumn{5}{|l|}{ Females } \\
\hline $0 \mathrm{~min}$ & $\begin{array}{l}218 \pm 17 \\
(n=13)\end{array}$ & $\begin{array}{l}176 \pm 18 \\
(n=13)\end{array}$ & $\begin{array}{l}204 \pm 42 \\
(n=13)\end{array}$ & $\begin{array}{l}172 \pm 23 \\
(n=12)\end{array}$ \\
\hline $60 \mathrm{~min}$ & $213 \pm 20$ & $202 \pm 25$ & $240 \pm 55$ & $212 \pm 22$ \\
\hline
\end{tabular}

Nonfasting blood glucose levels $\mathrm{mg} / \mathrm{dl}$ prior to glucose challenge $\mathrm{mg} / \mathrm{dl}$ and $60 \mathrm{~min}$ after glucose challenge, in long-term infection of male and female $\mathrm{C} 3 \mathrm{H} / \mathrm{HeJ}$ mice with EMCV-D. The data are expressed as the mean glucose concentration \pm SEM. These animals did not become diabetic in response to the virus at any time during the infection

Table 5. Effect of the D variant of EMCV on the mortality rate of $\mathrm{C} 3 \mathrm{H} / \mathrm{HeJ}$ mice

\begin{tabular}{llll}
\hline Sex & 7 days & 14 days & 21 days \\
\hline $\begin{array}{c}\text { Males } \\
(n=13)\end{array}$ & $15 \%$ & $38 \%$ & $46 \%$ \\
$\begin{array}{c}\text { Females } \\
(n=13)\end{array}$ & $0 \%$ & $0 \%$ & $7 \%$ \\
\hline
\end{tabular}

Effect of the D variant of EMCV on the mortality rate of $\mathrm{C} 3 \mathrm{H} / \mathrm{HeJ}$ mice in males and females at 7,14, and 21 days after infection. The data are expressed as a percentage of EMCV-D infected mice which died by 7,14 and 21 days post-infection. Only males were highly sensitive to the virus, with almost half succumbing by 21 days post-infection $(p<0.01)$

$\mathrm{C} 3 \mathrm{H} / \mathrm{HeJ}$ mice were infected with the virus. Female mice did not become hyperglycaemic (Table 1), and at killing 5 days after infection showed little exocrine or endocrine pancreatic involvement.

\section{Long-term infection of male and female $\mathrm{C} 3 \mathrm{H} / \mathrm{HeJ}$ mice with $E M C V-D$}

In an effort to determine if the exocrine lesion of the males would persist or undergo resolution, and whether an islet lesion would chronically develop, mice were infected with the virus and blood glucose monitored weekly for 21 days. No alterations in blood glucose levels were seen over this period (Table 4). However, mortality in these infected mice at 21 days was significant $(p<0.01)$, suggesting that severe exocrine lesions ultimately were not compatible with life (Table 5).

Female $\mathrm{C} 3 \mathrm{H} / \mathrm{HeJ}$ mice were resistant to the exocrine tropism of the virus at 5 days of infection. These mice were also found to be resistant to acinar destruction at 21 days of infection. Blood glucose concentrations did not vary from controls throughout the time course (Table 4), and mortality at 21 days was signifi- cantly less $(p<0.01)$ than that of male $\mathrm{C} 3 \mathrm{H} / \mathrm{HeJ}$ mice (Table 5).

A more sensitive indicator of islet lesions is the glucose tolerance test. This test was performed on male and female $\mathrm{C} 3 \mathrm{H} / \mathrm{HeJ}$ mice before and 7,14 , and 21 days after infection. Blood glucose values, $1 \mathrm{~h}$ after a glucose challenge, were not elevated in either sex at any time throughout the infection (Table 4). Pancreatic insulin levels were slightly lower than controls. However, this difference was not significant (Table 2).

\section{Effect of castration on EMCV-D susceptibility of male mice}

Since it was determined that the exocrine lesion in $\mathrm{C} 3 \mathrm{H} / \mathrm{HeJ}$ mice was an apparent gender-specific phenomenon, with females resistant to the acinar destruction, castration of male $\mathrm{C} 3 \mathrm{H} / \mathrm{HeJ}$ mice was performed. Blood glucose concentrations were not elevated from control levels in either the castrated group or the shamoperated group of mice (Fig. 2). Histological evaluation of the pancreata of these animals did not show any protective effect against the development of the exocrine lesion attributable to castration (Table 3 ).

In order to assess the efficacy of the castration procedure, male SJL/J mice were also castrated. Castration of these mice did demonstrate a protective effect against the induction of diabetes. Only $33 \%$ of the castrated animals infected with EMCV-D developed diabetes, as compared to the $100 \%$ induction of diabetes in the sham-operated $\mathrm{SJL} / \mathrm{J}$ mice.

\section{Effects of EMCV-B infection}

The B variant of EMCV was found not to be diabetogenic in either the $\mathrm{SJL} / \mathrm{J}$ strain or the $\mathrm{C} 3 \mathrm{H} / \mathrm{HeJ}$ strain of mice (Table 1).

The exocrine pancreas of $\mathrm{C} 3 \mathrm{H} / \mathrm{HeJ}$ mice was not affected by the $\mathrm{B}$ variant of the virus. This was verified in the scoring of exocrine destruction (Table 3 ).

\section{Infection with $E M C V-B$ prior to infection with $E M C V-D$}

Pretreatment with the B variant was found to protect $\mathrm{C} 3 \mathrm{H} / \mathrm{HeJ}$ animals from developing exocrine damage caused by infection with the $D$ variant. The number of animals that exhibited $50 \%$ or greater exocrine involvement was reduced to $11 \%$, as compared to mice receiving D variant alone ( $90 \%$ ) (Table 3 ). No perturbations in blood glucose were seen in these animals (Table 1). Histologically, the endocrine pancreas appeared to be relatively uninvolved, with no alterations in the islet cells. Pancreatic insulin concentrations in pretreated animals were found to be similar to those in animals receiving EMCV-D alone (Table 2). 


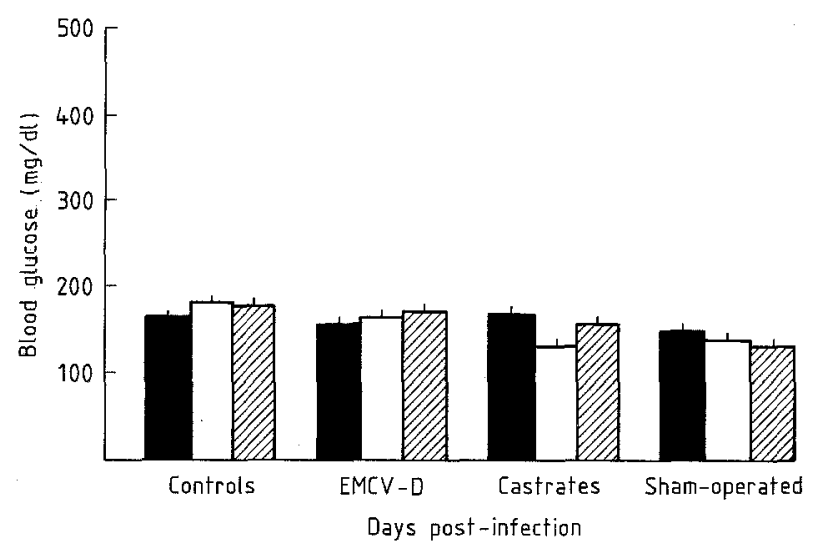

Fig. 2. Castration of male $\mathrm{C} 3 \mathrm{H} / \mathrm{HeJ}$ mice $(n=14)$ infected with EMCV-D does not significantly alter blood glucose levels from D variant only $(n=6)$, sham-operated $(n=14)$, or uninfected mice $(n=21)$ prior to infection (Pre) (solid boxes), 3 days (open boxes), and 5 days (diagonal boxes) post-infection

$\mathrm{SJL} / \mathrm{J}$ mice that were infected with the $\mathrm{B}$ variant three days prior to infection with the $\mathrm{D}$ variant showed marked reduction in the development of diabetes. Only $8 \%$ of the animals became diabetic, as compared to $90 \%$ of those infected with the D variant alone (Table 1).

\section{Coinfection with equal doses of variants $B$ and $D$ of $E M C V-D$}

Concomitant administration of both variants of EMCV was performed to determine the importance of the three-day preincubation period with $B$ variant in the pretreatment studies. Equal doses of $B$ and $D$ variants protected against the development of the exocrine lesion in $\mathrm{C} 3 \mathrm{H} / \mathrm{HeJ}$ mice. None of the animals, when scored for exocrine damage, possessed this type of lesion (Table 3).

\section{Coinfection with unequal doses of $B$ and $D$ variants of $E M C V$}

Treatment of $\mathrm{C} 3 \mathrm{H} / \mathrm{HeJ}$ animals with a lowered dose of $\mathrm{B}$ variant $(1: 100 ; \mathrm{B}: \mathrm{D})$ was performed to determine if the protective effect of $B$ was a dose-dependent phenomenon. The exocrine lesion of male $\mathrm{C} 3 \mathrm{H} / \mathrm{HeJ}$ mice again was found to be blocked by the $\mathrm{B}$ variant, even at this much-reduced concentration of virus (Table 3 ). This protection, however, was not $100 \%$, as it was with administration of equal doses of the two variants. Twentynine percent of the animals exhibited exocrine lesions involving greater than $50 \%$ of the pancreas. This is significantly reduced from $D$ variant only treated mice $(p<0.01)$. The mean score for exocrine destruction was also decreased to approximately half the score for EMCV-D only infected mice (Table 3). The islet cells did not appear to be involved, and pancreatic insulin levels were found to be similar to D variant only infected animals (Table 2).

\section{Discussion}

The results of experiments with $\mathrm{C} 3 \mathrm{H} / \mathrm{HeJ}$ mice, known to be resistant to the $M$ strain of the virus, showed that these animals are also resistant to the diabetogenic effect of the D variant, even though the animals do sustain a viral infection. However, the pattern of infection differs from that described previously for diabetogenic EMCV. The infection is not confined to the islets; rather, an acute pancreatitis develops with little direct islet involvement. The pancreatitis seen in these animals is reminiscent of that produced by the non-diabetogenic $\mathrm{E}$ strain of the virus, in which extensive coagulation necrosis of pancreatic acinar cells occurs [3]. Human viruses also show this change in pathogenesis. The Coxsackie Group B viruses, which like EMCV are picornaviruses, demonstrate a pancreopathy characterized by acinar destruction [14-16]. However, in some instances these viruses not only affect exocrine tissue, but also can destroy endocrine cells $[15,17,18]$. Although the exact reason for this change of tropism from endocrine to exocrine cells remains to be fully elucidated, genetically determined differences in the expression of viral receptors is a likely possibility.

Although the decrease in pancreatic insulin content in EMCV-D infected $\mathrm{C} 3 \mathrm{H} / \mathrm{HeJ}$ mice could be used to argue that $B$ cells are infected by the virus, it seems more plausible that the decrease is due to the exocrine destruction of islets in regions of extensive autolysis and necrosis, since remaining islets appear to possess normal islet cytoarchitecture and well-granulated endocrine cells. Additionally, since blood glucose concentrations are not elevated, even in response to a glucose challenge, a significant number of uninfected $B$ cells must be present. To fully resolve this question, studies employing an antibody to EMCV-D to demonstrate the presence or absence of virus in $B$ cells are warranted.

The results of the present studies with EMCV-D infected SJL/J male mice are in agreement with previous reports [9]. These mice are susceptible to the diabetogenic action of the D variant of EMCV. Therefore, although the $\mathrm{D}$ variant elicited an altered pathology in $\mathrm{C} 3 \mathrm{H}$ mice, the virus was still diabetogenic when given to an appropriate strain.

$\mathrm{C} 3 \mathrm{H} / \mathrm{HeJ}$ mice have been reported to have a macrophage defect. Macrophages from these mice are unable to achieve a differentiated state in vivo or in vitro, and to lose $\mathrm{Fc}$ receptor-mediated phagocytosis [19]. However, this macrophage defect is not reponsible for the altered tropism of the virus, since infection with EMCV of macrophage-normal LPS responsive $\mathrm{C} 3 \mathrm{HeB} / \mathrm{FeJ}$ mice also produced the acinar tropism. These experiments indicate that this exocrine effect was not due to retrovirus activation, since $\mathrm{C} 3 \mathrm{HeB} / \mathrm{FeJ}$ mice have been shown to be free of the mammary tumour virus that is present in $\mathrm{C} 3 \mathrm{H} / \mathrm{HeJ}$ mice [20].

Female $\mathrm{C} 3 \mathrm{H} / \mathrm{HeJ}$ mice did not develop pancreatitis, even after an extended infection period. Therefore, 
it can be concluded that females are not very susceptible to the lytic effects of the virus on the exocrine pancreas. Whether this is due to the presence of estrogens, a receptor difference, a more effective immune response to the virus, or to a combination of these factors, remains to be determined.

The degree of pancreatitis in long-term infected males was less than that seen in acutely infected mice. This is believed to be due to the high mortality rate in these infected males. At necropsy, gross signs of pancreatitis were evident in the mice that died before completion of the experiment. This suggests that the surviving mice did not receive as severe a pancreatic insult as did the mice that died.

Previous reports have shown that castration of male $\mathrm{SJL} / \mathrm{J}$ mice has a protective effect against the development of diabetes by the virus [21]. In the present studies, castration of male $\mathrm{C} 3 \mathrm{H} / \mathrm{HeJ}$ mice did not alter the expression of the acinar lesion, whereas castration of male $\mathrm{SJL} / \mathrm{J}$ mice did decrease the incidence and severity of diabetes with the $\mathrm{D}$ variant. While it is still possible that enough testosterone was present in the $\mathrm{C} 3 \mathrm{H} / \mathrm{HeJ}$ animals to potentiate the exocrine infection, it seems equally plausible, based on the results of these studies, that the mechanisms whereby castration protects against the diabetogenic effects of the $\mathrm{D}$ variant in $\mathrm{SJL} / \mathrm{J}$ mice are not operative in the development of the exocrine lesion in $\mathrm{C} 3 \mathrm{H} / \mathrm{HeJ}$ males.

In the present studies the $\mathrm{B}$ variant does not affect the exocrine tissue of $\mathrm{C} 3 \mathrm{H} / \mathrm{HeJ}$ males, nor does it produce diabetes in susceptible SJL/J mice. The nondiabetogenicity of EMCV-B in SJL/J mice agrees with previous reports [9]. Therefore, the two viruses can be more broadly classified as virulent (D) or nonvirulent (B).

Preinfection or coinfection with equal concentrations of the two variants, B and D, resulted in almost complete protection from the acinar lesions. Coinfection of $\mathrm{C} 3 \mathrm{H} / \mathrm{HeJ}$ mice with a much lowered dosage of the $B$ variant, than the $D$ variant, resulted in reduction of the exocrine lesions to about $50 \%$ of $\mathrm{D}$ variant-only infected mice. The protection afforded by the B variant can be explained by several mechanisms. The B variant could be eliciting an antibody response that acts to inhibit replication of the $\mathrm{D}$ variant, since the two variants are serologically identical [9]. This is especially true for the preinfection experiments. The 3 day period prior to $D$ variant treatment could allow the production of antibodies against $\mathrm{B}$, which would also inactivate the $\mathrm{D}$ variant. However, the protection is not complete in the preinfection experiments, suggesting that the response to the $\mathrm{B}$ variant may be waning in some animals. This effect would not be consistent with an antibody response. Another explanation for the protective mechanism by which the $B$ variant acts is by the generation of an interferon response. According to Yoon and coworkers [9], the B variant is a potent inducer of interferon in $\mathrm{SJL} / \mathbf{J}$ mice and in vitro, whereas the $\mathrm{D}$ variant is a poor inducer. Interferon is often detectable within hours of a viral infection and may constitute one of the earliest mechanisms of defense [22, 23]. Stimulation of interferon production by the $B$ variant could block the acinar tropism of the D variant. Equal dosages of B and D could result in the production of a quanity of interferon which would be sufficient to block $D$ variant replication. Reduction in the amount of $B$ variant would result in a decreased interferon response. This decreased response might not be sufficient to totally block $D$ variant replication, resulting in some degree of acinar destruction, as was seen in the present experiments. Likewise, the levels of interferon present in the preinfection experiments would be decreasing at 3 days post-infection and might not be high enough to completely block $D$ variant destruction of the exocrine pancreas. Similar findings were reported for the B and D variants in protection against diabetes in susceptible strains of mice.

These studies demonstrate that a plaque isolated virus that is very diabetogenic in some inbred strains of mice produces a completely different pathology in the pancreas of other inbred strains. A similar occurrence in man could explain why similar picornaviruses like the Coxsackie viruses may infect many individuals but produce diabetes in only a few.

Acknowledgements. The authors would like to thank Ms. M. Stober for her skillful preparation of the manuscript. This study was supported by National Institutes of Health grants ES03066, ES03456, and AI19968. GL Wilson is the recipient of a National Institutes of Health Research Career Development Award ES00150.

\section{References}

1. Albin J, Rifkin H (1982) Etiologies of diabetes mellitus. Med Clin North Am 66: 1209-1226

2. Gamble DR, Taylor KW (1960) Seasonal incidence of diabetes mellitus. Br Med J 3: 631-633

3. Craighead JE (1966) Pathogenicity of the $M$ and $E$ variants of the encephalomyocarditis (EMC) virus. II. Lesions of the pancreas, parotid and lacrimal glands. Am J Pathol 48: 375-386

4. Craighead JE, McLane MF (1968) Diabetes mellitus: Induction in mice by encephalomyocarditis virus. Science 162: 913-914

5. Craighead JE, Steinke J (1971) Diabetes mellitus-like syndrome in mice infected with the encephalomyocarditis virus. Am J Pathol 63: 119-134

6. Boucher DL, Notkins AL (1973) Virus-induced diabetes mellitus. I. Hyperglycemia and hypoinsulinemia in mice infected with encephalomyocarditis virus. J Exp Med 137: 1226-1239

7. Craighead JE (1966) Pathogenicity of the $M$ and $E$ variants of the encephalomyocarditis (EMC) virus. I. Myocardiotropic and neurotropic properties. Am J Pathol 48: 333-345

8. Boucher DW, Hayaski K, Rosenthal J, Notkins AL (1975) Virus induced diabetes. III. Influence of sex and strain of the host. J Infect Dis 131: 462-466

9. Yoon JW, McClintock PR, Onodera T, Notkins AL (1980) Virusinduced diabetes mellitus. XVIII. Inhibition by a non-diabetogenic variant of encephalomyocarditis virus. J Exp Med 152: 878-891

10. Nagafuchi S, Kohnoue E, Nakamura M, Nakano S, Koga T, Nakayama M, Niho Y, Takaki R (1985) Protection of EMC-D virus induced diabetes mellitus by Corynebacterium parvum. Diabetes 34: $61 \mathrm{a}$

11. Vogel SN, Rosenstreich DL (1979) Defective Fc receptor-mediated phagocytosis in $\mathrm{C} 3 \mathrm{H} / \mathrm{HeJ}$ macrophages. I. Correction by lymphokine-induced stimulation. J Immunol 123: 2842-2850 
12. Wright $P$, Makulu $P$, Vichick $D$, Sussman $K$ (1971) Insulin immunoassay by back-titration; some characteristics of the technic and insulin preciptant action of alcohol. Diabetes 20: 33 45

13. Wilson GL, Chick WL, Appel MC (1979) Pancreatic islet cell monolayer culture: Immunoperoxidase staining and autoradiography. TCA Manual 5: 1193-1197

14. Cook SHS, Loria RM, Madge GE (1982) Host factors in Coxsackie virus B 4-induced pancreopathy. Lab Invest 46: 377-382

15. Toniolo A, Onodera T, Jordan G, Yoon JW, Notkins AL (1982) Virus-induced diabetes mellitus: Glucose abnormalities produced in mice by the six members of the Coxackie B virus group. Diabetes $31: 496-499$

16. Webb SR, Loria RM, Madge GE, Kibrick S (1976) Susceptibility of mice to group $\mathrm{B}$ Coxackie virus is influenced by the diabetic gene. J Exp Med 143: 1-8

17. Yoon JW, Onodera T, Notkins AL (1978) Virus-induced diabetes mellitus. XV. Beta cell damage and insulin-dependent hyperglycemia in mice infected with Coxackie virus B4. J Exp Med 148: 1068-1080

18. Yoon JW, Onodera T, Jenson AB, Notkins AL (1978) Virus-induced diabetes mellitus. XI. Replication of Coxsackie B3 virus in human beta cell cultures. Diabetes 27: 778-781

19. Vogel SN, Weedon LL, Moore RN, Rosenstreich DL (1982) Correction of defective macrophage differentiation in $\mathrm{C} 3 \mathrm{H} / \mathrm{HeJ}$ mice by an inteferon-like molecule. J Immunol 133: 299-305
20. Heiniga HJ, Dorey JJ (1980) Handbook on genetically standardized Jax mice, 3rd edn. The Jackson Laboratory, Bar Harbor, Maine, $\mathrm{p} 254$

21. Friedman SB, Grota LJ, Glasgow LA (1972) Differential susceptibility of male and female mice to encephalomyocarditis virus. Effects of castration, adrenalectomy, and administration of sex hormones. Infect Immun 5: 637-644

22. Stewart WE (1979) The interferon system. Springer, New York, pp 199-200

23. Preble OT, Friedman RM (1983) Biology of disease. Interferon-induced alterations in cells: relevance to viral and nonviral diseases. Lab Invest 49: 4-18

Received: 26 November 1985

and in revised form: 28 February 1986

Dr. Glenn L. Wilson

Department of Anatomy

University of South Alabama

College of Medicine

2042 Medical Sciences Building

Mobile, Alabama 36688

USA 